\title{
A hazai felsőoktatási jelentkezési döntések változása A regionális hatás
}

\section{Change in domestic tertiary-education applications Regional impact on decision making}

\author{
KURÁTH GABRIELLA, SIPOS NORBERT
}

\begin{abstract}
KURÁTH Gabriella: marketing tanácsadó, c. egyetemi docens, Pécsi Tudományegyetem, Rektori Kabinet, Közgazdaságtudományi Kar; 7622 Pécs, Vasvári P. u. 4.; kurath.gabriella@pte.hu; http://orcid.org/0000-0003-2279-5935

SIPOS Norbert: egyetemi adjunktus, Pécsi Tudományegyetem, Közgazdaságtudományi Kar; 7622 Pécs, Rákóczi út 80.; sipos.norbert@ktk.pte.hu; https://orcid.org/00000003-0238-758X
\end{abstract}

KULCSSZAVAK: felsőoktatás; jelentkezési döntések; vonzáskörzetek

ABSZTRAKT: A tanulmányban a hazai felsőoktatási jelentkezési döntésekkel foglalkozunk. A cél, hogy megvizsgáljuk a 2005/06 és a 2015/16 közötti évek jelentkezési számainak alakulását a regionális hatások kimutatásával. Eredményeink alapján a hazai intézmények vonzáskörzete átalakult, a csökkenő hallgatói létszámok mellett Budapest, valamint a nagyobb vidéki szellemi központok vonzereje növekedett, csökkentve az érdeklődést a kisebb felsőoktatási intézmények iránt. Így a gyengébb vonzerejü területeknek új lehetőségeket, stratégiákat kell találniuk a megváltozott helyzetben. A tanulmányban foglalkozunk az oktatási intézmények számára kötelező pályakövetési kutatásokkal, amelyek segítséget nyújthatnak munkájukhoz.

Gabriella KURÁTH: marketing manager, honorary associate professor, Rector's Office, Faculty of Business and Economics, University of Pécs; Vasvári P. U. 4., H-7622 Pécs, Hungary; kurath.gabriella@pte.hu; http://orcid.org/0000-0003-2279-5935

Norbert SIPOS: assistant professor, Faculty of Business and Economics, University of Pécs; Rákóczi út 80., H-7622 Pécs, Hungary; sipos.norbert@ktk.pte.hu; https://orcid.org/0000-0003-0238-758X

KEYWORDS: higher education; applicants' decisions; attraction area

ABSTRACT: The paper deals with Hungarian students regarding their decisions to apply for institutions of higher (tertiary) education. It examines the evolution of the application numbers for the last ten years in order to detect regional impacts, tendencies and potential deviations.

We analyse the numbers of applicants and their ratios to admitted students, drawing the identifiable conclusions. On this basis, we suggest a possible and suitable direction for the future, potentially supporting decision-making processes for institutional strategies.

We worked with secondary data sources provided by the Hungarian Educational Authority related to the tertiary education applications and admissions, sorting and grouping

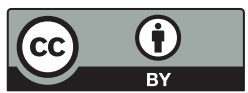


them according to predefined criteria to visualise changes in the territorial, institutional and subjective factors in first-place applications, total numbers of applications and admissions.

Our results show a drastic change in areas of attraction to the Hungarian tertiary educational institutions. There was a 'golden age' in the early millennium evidenced by a rapid growth of short-cycled student inflow which ended just a few years later. Also, regular applications suffered a fall in 2010-2011, affected by several external and internal factors (Bologna system, extended opportunities for studying and working abroad, governmental funding cuts, etc.). In total, besides the decreasing number of potential students, only Budapest has been able to generate a significant attraction and retaining power. This, in turn, results in an even stronger centralisation of Hungarian tertiary education.

Furthermore, another strong change can be seen: In addition to the Hungarian capital, the traditional scientific centres were also able to attract students from territories with previously smaller tertiary education potential. By the same token, less attractive areas are in need to find new opportunities and strategies not to risk closure of their operations.

In the study, we draw attention to the analysis of the regional aspects of applications. Many have already written about the importance of a marketing information system. We focus on the role of the mandatory Graduate Career Tracking System instead. It is crucial for institutions to demonstrate the possible ways of utilisation and embedding the data collected and analysed since 2010 into institutional processes to complement the data aggregation by the State Administrative Database.

\section{Bevezető}

A világban zajló megatrendek - a globalizáció, a gyors technológiai változások, a demográfiai folyamatok és a változó társadalmi igények - a felsőoktatásban számos jelentős változást indítottak el az elmúlt 20 évben (Berács et al. 2015; Duga, Szontágh 2012; Halász 2012; Hrubos 2012, 2014; Keresztes 2014; Komlódiné Pozsgai 2014; Kováts, Temesi 2018; Polónyi 2012, 2014, 2016, 2018), így például a tömegesedést, amely maga után vonja egy új minőségbiztosítási rendszer kialakításának szükségességét (ennek egyik elemét jelenti a pályakövetés). Megváltozott az oktatás általános kerete is, a klasszikus értelemben vett oktatói tudás kisajátíthatósága csökkent, a közvetlen tanár-diák kapcsolat köteléke lazult a diáklétszám növekedése, valamint a személyes jelenlét kisebb igénye miatt. Az online ismeretanyagok, a távoktatás és az online kurzusok (MOOCs - Massive Open Online Courses) megrengették a felsőoktatás évszázados elefántcsonttornyát. A bolognai rendszer bevezetésével a nemzetközi hallgatói mobilitás is megerősödött.

Tanulmányunkban a hazai felsőoktatási kihívásokra fókuszálunk, és elsősorban a hazai felsőoktatási jelentkezési döntésekkel foglalkozunk. A demográfiai apály, a csökkenő jelentkezések - ezen belül a levelező tagozatra történő jelentkezők számának visszaesése - arra ösztönzik a felsőoktatási intézményeket, hogy kitörési pontokat keressenek.

Filep és Tamándl (2011) a sikeres intézményi pályakövetés müködésében látja a felsőoktatás és a munkaerőpiac közti információáramlási hiány leküzdését, amely ma a felsőoktatás egyik nagy problémája. 


\section{A hazai felsőoktatás kihívásai}

A megváltozott körülmények között a hazai felsőoktatás jövője a minőségi stratégiák középpontba állításától függ. Olyan folyamatokat kell elindítani, amelyek felerősítik az intézmények közötti versenyt. Mindez tudatosabb intézményi gazdálkodást, valamint tervezett marketing- és menedzsmenttevékenységet kíván, mivel hatása van a középiskolások szak- és intézményválasztására, a felsőoktatási képzések minőségére és az intézmények nemzetközi versenyképességére is. Kiemelt feladatként jelenik meg a felsőoktatás és a munkaerőpiac összhangjának megteremtése. Az elmúlt időszakban a magyarországi helyzetről sok elemzés született, ezekből a témánkhoz kapcsolódva négy főbb tényezőt emelünk ki (Berács et al. 2015; Berács et al. 2017; Fokozatváltás a felsőoktatásban; Kováts, Temesi 2018; Polónyi 2016, 2018).

- A hallgatói létszám csökkenése ma már tény, a rövid ciklusú képzéseknek az évezred elején tapasztalt ugrásszerü növekedése és felpörgető ereje megszűnt, ezzel párhuzamosan (időben eltolva) visszaesett a nem nappali képzésben részt vevő hallgatói létszám, amelyet még nem követett az oktatói állományváltozás az időbeli eltolódásból adódóan. A nappali tagozatos létszám 2011-től stagnál, illetve csökken. A potenciális rétegeknek - vagyis akik nem akarják vagy nem tudják tanulmányaikat folytatni - a megnyerése csak jelentős változás révén érhető el.

- Ugyanakkor a nemzetköziesités a hazai felsőoktatásban is kulcskérdéssé vált, növekszik a külföldi hallgatók aránya, amely válasz a globális környezet megjelenéséből adódó kihívásokra. A munkaerőpiac is nemzetközivé vált (friss diplomások emigrációja), ami a diplomával kapcsolatos minőségi elvárások módosulását is magával hozza a hazai felsőoktatásban.

- A képzésekben a Bologna-folyamatnak köszönhetően rövidebb ciklusra kell átállnia a magyar felsőoktatásnak, a munkaerőpiac gyorsan felszívja az alapdiplomával rendelkezőket.

- A felsőoktatás finanszírozásában is jelentős változás következett be, nevezetesen a GDP-arányos költségvetési kiadások, az állami finanszírozás visszaszorulása, amely részben pótolható az Európai Uniótól érkező forrásokkal, illetve a tehervállalás arányainak megváltoztatásával (részben a családok, részben a vállalatok révén). Nem kérdés, hogy ez radikálisan csökkenti a hozzáférési esélyegyenlőséget. A kormányzati finanszírozással kapcsolatos döntések révén a családok jobban megfontolják a továbbtanulási döntést, értékalapú döntéshozatal kerül elötérbe.

Mindezek ellenére fontosnak tartjuk kiemelni, hogy a felsőoktatásban való részvétel növekvő mértékét szeretnénk és várjuk közép- és hosszú távon. Ezzel kapcsolatban komoly feladatai vannak a magyar felsőoktatási rendszernek. Reagálnia kell a felsőoktatást érintő változásokra, nemzetközi kontextusban kell biztosítani olyan képzéseket, amelyeknek köszönhetően a magyar hallgatók itthon maradnak, a külföldiek pedig ide jönnek tanulni. 


\section{Felsőoktatási jelentkezések és a regionális hatások}

Az elmúlt években több felmérést is végeztek, amelyek a felvételi döntéseket vizsgálták (Balogh 2015; Kuráth, Héra-Tóth, Sipos 2017; Olsovszkyné Némedi 2014; Rámháp 2017; Rechnitzer 2010, 2011; Törőcsik 2015). Ezekből egyértelműen kiderült, hogy a jelentkező először az érdeklődési körének megfelelő szakot vagy képzést keresi és csak ezt követően választ intézményt, várost. A továbbtanulást befolyásoló tényezők között a képzési kínálaton túl kiemelt szerepe van az oktatási intézmény hírnevének, a karrierszempontoknak és a hallgatók számára kínált szolgáltatásoknak. Egyre fontosabbá válnak az anyagi megtérülési szempontok is, vagyis a jelenlegi képzési és megélhetési költségek összehasonlítása a jövőben elérhető „hozamokkal”. Versenyelőnyt jelent az oktatási intézmény városának vonzereje: az oktatási intézmény települése, a képzés helyének a diák lakóhelyétől való távolsága és a régió munkaerőpiaci lehetőségei. A hallgatói választást befolyásolja, hogy mely centrum nyújt nagyobb lehetőséget az elhelyezkedéshez és a hosszú távú munkavállaláshoz. Vagyis erőteljesen megjelenik a gazdasági hatás, amely befolyásolja egy-egy település vagy intézmény szívó vagy taszító potenciálját is.

Az egyes intézmények versenyképességét közvetlenül tükrözi, hogy milyen nagyságú és összetételű a felvételiző diákok köre, ezért a felsőoktatási jelentkezések alakulását régiók és megyék szerinti bontásban vizsgáltuk. Az adatok elemzésekor döntően az Oktatási Hivatal által rendelkezésünkre bocsátott, a felvételizőkre vonatkozó adatbázisokat használtuk fel a 2005/06 és a 2015/16-os felvételi időszakokra vonatkozóan. Ebben a tíz évben számos változás történt, az intézményi összevonásoktól kezdve egyes képzések, karok áthelyezésén át a felvételi jelentkezési eljárásig bezárólag. Mindezekre tekintettel voltunk, és sikerült az elemzésben egységes szerkezetet kialakítanunk. A jelentkezésekkel kapcsolatos adatok a normál, a keresztféléves és a pótfelvételi eljárásban történő jelentkezéseket tartalmazzák, ebből adódóan kimaradnak a szakirányú továbbképzések és a doktori képzések a vizsgálatunkból. Ezen felül nem jelenik meg a külföldi állampolgárok felvételi eljárása sem.

Az első helyes jelentkezés a felvételiző alapvető preferenciáit mutatja, míg az összes jelentkezés az intézmény, a kar, a szak iránti társadalmi érdeklődés mértékét érzékelteti. Nem tudjuk az összes hatást figyelembe venni, ugyanakkor a hangsúlyok eltolódása megragadható. Általában nem az abszolút értékeket mutatjuk be, hanem az arányokban, megoszlásokban mutatkozó elmozdulásokat, amelyek jobban kifejezik a trendeket.

Az adatok egyértelműen mutatják, hogy csökkent az érettségizők száma, ami a negatív demográfiai folyamatokhoz is kapcsolódik. Az érettségizők jelentik a felsőoktatásba jelentkezők bázisát. Ugyanakkor ki kell emelnünk, hogy lényegesen nagyobb mértékű volt 2010 és 2015 között a jelentkezők és a felvettek számában történő csökkenés, mint az érettségiző korosztály létszámában. Ez az oktatáspolitikában 2011-től bekövetkezett változásokkal magyarázható. Polónyi (2016) 
szerint a felsőoktatásba újonnan belépő hallgatók számának csökkenése 10 évre visszamenőleg kétszer akkora volt, mint a korosztályi létszámban azonosítható visszaesés. Ezt súlyosbította az államilag finanszírozott hallgatóknál kimutatott 20\%-os visszaesés.

A jelentkezői létszám jelentős visszaesése után az elmúlt években enyhe növekedést tapasztaltunk, miközben az érettségizők száma folyamatosan csökkent (1. ábra). A legfrissebb adatok szerint a teljes felvételi létszám csökkenése megállt, a következő időszakban az érettségizők száma várhatóan kissé emelkedik. Így valószínűleg a jelentkezők száma is emelkedni fog, amennyiben a bejutási feltételek nem változnak (Polónyi 2018). Összességében nem befolyásolja jelentősen a képet, hogy munkarend szerint eltérő tendenciák azonosíthatóak: a levelező képzésekre való jelentkezésben az erőteljes visszaesés a 2005/06-os tanév után szinte azonnal jelentkezett (ami a rövid ciklusú képzésekbe lépők „kifutására” vezethető vissza); míg ez a nappali tagozaton jóval később, csak a 2011/12-es akadémiai évet követően következett be.

A regionális különbségek jelentősen befolyásolják a jelentkezési aspirációkat (Kuráth 2008; Olsovszkyné Némedi 2014; Polónyi 2018; Rechnitzer 2010). Polónyi (2018) tanulmányában összegzi, hogy az elmúlt években jól érzékelhetően növekedett a fővárosi dominancia a felsőoktatásba történő első helyes jelentkezésekben. Míg 2009-ben az első helyes jelentkezések nagyobb része a vidéki intézményekbe történtek, 2012-től a fővárosi intézmények kerültek elötérbe, és 2017-re már a jelentkezések 53\%-a budapesti intézménybe történt. A felvettek létszámadataiból világosan látszik, hogy a 2010-es felsőoktatás-politikai irányváltás nyomán bekövetkezett felsőoktatási létszámmegszoritás vesztese a vidéki felsőoktatás.

Jelentős különbségek mutathatók ki régiónként a jelentkezők megoszlásában (1. táblázat), ami befolyásolja az intézményi jelentkezéseket is. Budapest kiemelt szerepe mellett a létszámok alapján Dél-Dunántúl és Nyugat-Dunántúl

1. ábra: A felsőoktatásba normál eljárásban belül jelentkezők száma és az érettségizők száma Number of students applying for tertiary-level education in normal application process and the number of students finishing secondary-level education

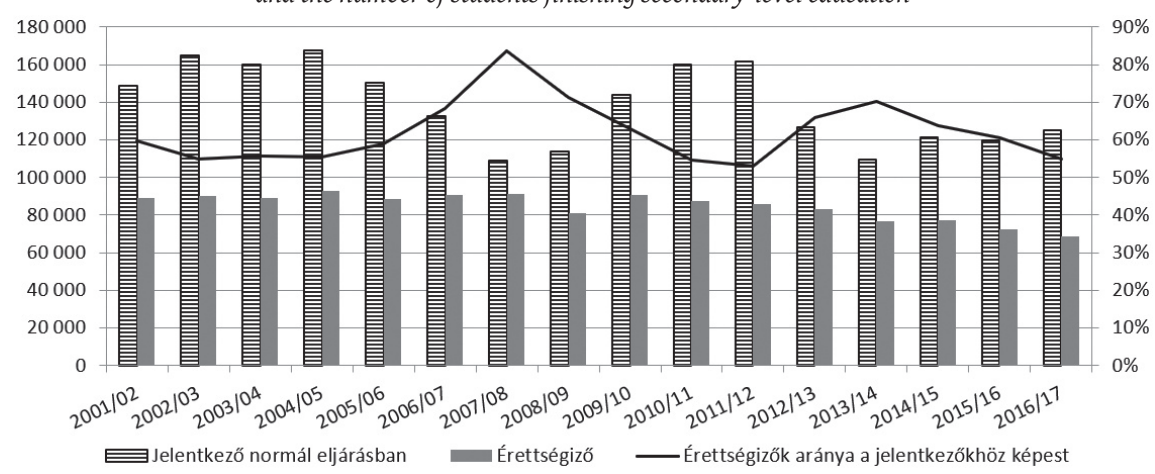

Adatok forrása: Oktatási Hivatal, www.felvi.hu és www.ksh.hu. 
1. táblázat: Az első helyes jelentkezők és a felvettek aránya régiónként a középiskola/lakóhely alapján (2005/06-2015/16)

Ratio of students applied in first place for and admitted to third-level education by regions based on residency/high school region (2005/06-2015/16)

\begin{tabular}{|c|c|c|c|c|c|c|c|c|c|c|c|}
\hline Régió & $2005 / 0$ & $006 /$ & $77 / 0$ & $2008 / 09$ & $2009 / 10$ & $2010 / 11$ & $2011 / 12$ & $2012 / 13$ & $2013 / 14$ & $2014 / 15$ & $2015 / 16$ \\
\hline \multicolumn{12}{|c|}{ Első helyen jelentkezettek aránya (\%) } \\
\hline Dél-Alföld & 12,9 & 13,0 & 12,8 & 13,0 & 13,5 & 13,2 & 13,0 & 12,9 & 12,8 & 12,7 & 13,0 \\
\hline Dél-Dunántúl & 9,2 & 9,2 & 8,8 & 8,6 & 8,6 & 8,7 & 8,7 & 8,8 & 8,7 & 8,3 & 8,4 \\
\hline Észak-Alföld & 14,9 & 14,9 & 14,5 & 14,7 & 15,2 & 15,2 & 14,9 & 14,4 & 14,7 & 14,6 & 15,1 \\
\hline Észak-Mo. & 11,7 & 12,0 & 11,8 & 11,3 & 11,7 & 11,4 & 11,3 & 11,0 & 10,8 & 10,5 & 10,9 \\
\hline Közép-Dt. & 10,6 & 10,6 & 10,5 & 10,6 & 10,3 & 10,5 & 10,6 & 10,5 & 10,2 & 10,0 & 10,3 \\
\hline Közép-Mo. & 32,0 & 31,3 & 32,2 & 32,9 & 31,8 & 31,7 & 32,0 & 33,0 & 33,5 & 34,9 & 33,0 \\
\hline Nyugat-Dt. & 8,8 & 9,0 & 9,3 & 9,0 & 9,0 & 9,4 & 9,4 & 9,3 & 9,2 & 9,0 & 9,3 \\
\hline \multicolumn{12}{|c|}{ A felvettek aránya (\%) } \\
\hline Dél-Alföld & 13,1 & 13,2 & 12,8 & 13,1 & 13,2 & 12,9 & 12,7 & 12,5 & 12,8 & 12,6 & 12,8 \\
\hline Dél-Dunántúl & 9,2 & 9,2 & 8,8 & 8,8 & 8,9 & 9,0 & 8,8 & 8,9 & 8,7 & 8,4 & 8,5 \\
\hline Észak-Alföld & 14,8 & 14,9 & 14,5 & 14,9 & 15,1 & 15,2 & 14,8 & 14,2 & 14,8 & 14,8 & 15,2 \\
\hline Észak-Mo. & 11,7 & 11,8 & 11,6 & 11,2 & 11,6 & 11,3 & 11,5 & 10,8 & 10,9 & 10,4 & 10,9 \\
\hline Közép-Dt. & 10,8 & 10,6 & 10,5 & 10,6 & 10,4 & 10,6 & 10,6 & 10,6 & 10,2 & 9,9 & 10,3 \\
\hline Közép-Mo. & 31,2 & 30,8 & 32,4 & 32,1 & 31,5 & 31,2 & 31,9 & 33,2 & 33,0 & 34,3 & 32,4 \\
\hline Nyugat-Dt. & 9,3 & 9,5 & 9,4 & 9,3 & 9,3 & 9,9 & 9,8 & 9,8 & 9,6 & 9,6 & 9,9 \\
\hline \multicolumn{12}{|c|}{ Felvettek / elsö helyen jelentkezettek aránya (\%) } \\
\hline Dél-Alföld & 72,3 & 74,5 & 77,9 & 85,6 & 74,6 & 70,2 & 69,9 & 71,4 & 76,2 & 70,6 & 68,3 \\
\hline Dél-Dunántúl & 71,7 & 73,7 & 77,5 & 87,0 & 78,9 & 74,8 & 72,6 & 73,4 & 76,7 & 72,0 & 69,9 \\
\hline Észak-Alföld & 71,1 & 73,7 & 77,5 & 85,8 & 75,6 & 71,4 & 71,2 & 71,9 & 77,2 & 71,6 & 70,1 \\
\hline Észak-Mo. & 71,4 & 72,9 & 76,8 & 84,1 & 75,5 & 70,9 & 72,5 & 72,0 & 76,9 & 70,2 & 69,3 \\
\hline Közép-Dt. & 72,9 & 74,0 & 77,6 & 85,2 & 76,5 & 72,1 & 71,9 & 73,9 & 76,6 & 70,3 & 69,5 \\
\hline Közép-Mo. & 70,0 & 72,5 & 78,4 & 82,7 & 75,4 & 70,5 & 71,3 & 73,7 & 75,2 & 69,7 & 68,3 \\
\hline Nyugat-Dt. & 76,2 & 77,5 & 78,7 & 87,3 & 78,2 & 75,4 & 74,3 & 76,7 & 79,7 & 75,7 & 74,2 \\
\hline
\end{tabular}

Adatok forrása: az Oktatási Hivatal felvételi adatbázisai.

áll a lista végén. Dél-Dunántúl az egyetlen, ahol az első helyes jelentkezők száma tartósan 10000 fó alá csökkent. A vizsgált tíz évben a legnagyobb vesztes Dél-Dunántúl és Észak-Magyarország. Pozitív irányú elmozdulás követhető Közép-Magyarország, Észak-Alföld és Nyugat-Dunántúl régiókban.

A felvettek megoszlása hasonló képet mutat, azzal a különbséggel, hogy jelentösebb visszaesést tapasztalhatunk Közép-Dunántúlon is, valamint hogy a legjelentősebb csökkenés Észak-Magyarországon történt. Dél-Dunántúl az egyetlen régió, amely 7000 fö alatti felvett létszámmal rendelkezik. A felvettek és az elsö helyen jelentkezók arányában jelentős különbségeket nem fedezhetünk fel, egy kivétellel: Nyugat-Dunántúl eredményei 5-6\%-ponttal magasabbak az átlagnál. Összességében tehát nincsenek eltérések a bekerülés esélyeiben az egyes régiókban.

A továbbiakban azt vizsgáljuk, hogy vannak-e különbségek az adott régióban a legnagyobb felsőoktatási intézmények és a nagyobb létszámú fơvárosi egyetemek von- 
záskörzetei között (jellemzően a 2015/16-os felvételi időszakban legalább 3000 fős első helyes jelentkezői létszámokkal rendelkezők) a jelentkezői számokban (2. táblázat). Mindegyik régióból legalább egy intézményt tüntetünk fel. KözépMagyarország esetében - Budapest központi helyzetéből adódóan - a legnagyobb létszámú intézmények mellett specializált képzési profilú szakegyetemeket is szerepeltetünk.

A 2. táblázatban az adott régión belüli jelentkezések arányát tüntettük fel az összes jelentkezőből. A budapesti intézmények országos beiskolázási körzettel rendelkeznek, jellemzően mintegy 50\%-os saját régióból történő jelentkezési arányok mellett. A vidéki intézmények közül a Pannon Egyetem és a Széchenyi István Egyetem rendelkezik hasonló arányokkal, a többi intézmény esetében folyamatosan emelkedést tapasztalhatunk a vizsgált tíz évben, jellemzően $60-70 \%$ feletti a saját régiós jelentkezői kör, a Debreceni Egyetem és a Miskolci Egyetem esetében ez az arány megközelíti a 80\%-ot.

Az egyes megyék felsőoktatási vonzereje több tényezőtől függ, például a képzési kínálat minőségétől és sokszínűségétől. Fontos szempont a felsőoktatási intézmény beágyazottsága és kapcsolatrendszere a helyi társadalmi-gazdasági környezetben, sőt, maga a település is vonzó hatású a potenciális jelentkezők számára.

2. táblázat: Az első helyen jelentkezők régión belüli aránya a legnagyobb régiós és budapesti intézmények szerint, az adott kar képzési telephelye alapján (2005/06-2015/16)

Ratio of students applying in first place within the region for major regional and Budapest-seated tertiary-level education by institutions based on seat of faculties (2005/06-2015/16)

\begin{tabular}{lccccccccccc}
\hline \multicolumn{1}{c}{ Intézmény } & 2005 & 2006 & 2007 & 2008 & 2009 & 2010 & 2011 & 2012 & 2013 & 2014 & 2015 \\
& 106 & $/ 07$ & $/ 08$ & $/ 09$ & $/ 10$ & $/ 11$ & $/ 12$ & $/ 13$ & $/ 14$ & $/ 15$ & $/ 16$ \\
\hline Budapesti Corvinus Egyetem & 47,5 & 49,5 & 53,3 & 51,9 & 51,1 & 50,6 & 50,7 & 53,3 & 53,9 & 54,1 & 50,6 \\
Budapesti Gazdasági Egyetem & 56,1 & 55,4 & 59,0 & 58,9 & 56,5 & 54,7 & 55,3 & 56,1 & 54,8 & 58,2 & 53,3 \\
Budapesti Múszaki és & 45,8 & 44,8 & 46,5 & 46,5 & 45,0 & 44,5 & 45,7 & 46,5 & 45,2 & 46,3 & 44,6 \\
Gazdaságtudományi Egyetem & & & & & & & & & & & \\
Debreceni Egyetem & 72,9 & 73,3 & 72,7 & 76,9 & 77,5 & 77,3 & 76,6 & 77,6 & 78,8 & 79,0 & 79,3 \\
Eötvös Loránd Tudományegyetem & 54,7 & 53,1 & 55,6 & 54,9 & 54,3 & 55,1 & 54,7 & 54,9 & 53,1 & 54,8 & 51,0 \\
Miskolci Egyetem & 73,3 & 73,8 & 76,0 & 75,0 & 78,3 & 78,8 & 79,2 & 77,4 & 79,7 & 80,1 & 79,8 \\
Nemzeti Közszolgálati Egyetem & 37,7 & 41,0 & 38,0 & 41,3 & 39,0 & 40,7 & 36,4 & 30,2 & 31,3 & 33,5 & 28,5 \\
Nyugat-magyarországi Egyetem & 40,1 & 45,7 & 49,3 & 59,1 & 59,5 & 60,5 & 58,6 & 59,2 & 60,6 & 60,9 & 64,0 \\
Óbudai Egyetem & 52,1 & 51,9 & 54,6 & 53,7 & 53,4 & 52,4 & 54,3 & 52,7 & 53,2 & 52,9 & 52,9 \\
Pannon Egyetem & 45,5 & 47,9 & 50,1 & 50,1 & 52,7 & 53,7 & 53,2 & 52,8 & 52,9 & 52,1 & 50,0 \\
Pázmány Péter Katolikus Egyetem & 54,8 & 54,7 & 61,6 & 58,0 & 55,5 & 56,9 & 57,1 & 56,6 & 57,1 & 59,7 & 52,7 \\
Pécsi Tudományegyetem & 49,1 & 52,1 & 53,2 & 58,1 & 59,8 & 59,9 & 60,0 & 61,5 & 60,1 & 61,7 & 60,3 \\
Semmelweis Egyetem & 52,1 & 52,4 & 52,4 & 52,1 & 53,1 & 51,4 & 50,8 & 51,4 & 53,0 & 52,0 & 51,3 \\
Széchenyi István Egyetem & 43,7 & 46,8 & 52,0 & 49,1 & 52,3 & 51,9 & 49,6 & 50,5 & 49,0 & 50,2 & 47,3 \\
Szent István Egyetem & 54,1 & 57,9 & 56,3 & 58,8 & 57,2 & 59,5 & 58,2 & 54,3 & 55,6 & 54,8 & 50,2 \\
Szegedi Tudományegyetem & 69,9 & 68,8 & 70,0 & 71,6 & 72,5 & 72,5 & 74,0 & 74,3 & 74,2 & 75,3 & 74,1 \\
\hline
\end{tabular}

Adatok forrása: az Oktatási Hivatal felvételi adatbázisai. 
A 3. táblázat a helyi felvételizők arányával a megye megtartó erejére utal. Budapest folyamatosan javította pozícióját: míg 2005/06-ban 66,2\% döntött a helyben maradás mellett, addig 2015/16-ra már a felvételizők 86\%-a. Ez kihívást jelent a vidéki felsőoktatási intézmények számára, amelyre még nem találták meg a választ. Vidéken legmagasabb arányban Zala, Hajdú-Bihar, Borsod-AbaújZemplén megyében növekedett a felsőoktatás „helyben tartó” képessége. Erőteljes volt a csökkenés Tolna, Szabolcs-Szatmár-Bereg, Fejér, Komárom-Esztergom és Békés megyében.

A felsőoktatási intézménybe jelentkezők közül a helyi lakosok és a megyén kívüliek aránya mutatja a helyi felsőoktatás megyehatáron túlnyúló vonzerejét (2. ábra).

Ha a mutató értéke 1, akkor ugyanannyi hallgató került be a megyei felsőoktatásba, mint ahány felvett hallgató volt összesen a megyéből (helyben vagy máshova). A vonzerőt elemzésünkben akkor tekintjük kiemelkedőnek, ha a mutató eléri, illetve meghaladja az 1,5-öt.

3. táblázat: Az egyes megyék megtartó ereje a helyi felvételizők aránya alapján

$(\%, 2005 / 06-2015 / 16)$

Retaining power of counties based on share of locally resident applicants

(\%, 2005/06-2015/16)

\begin{tabular}{lrrrrrrrrrrrr}
\hline \multirow{1}{c}{ Megye } & $2005 /$ & $2006 /$ & $2007 /$ & $2008 /$ & $2009 /$ & $2010 /$ & $2011 /$ & $2012 /$ & $2013 /$ & $2014 /$ & $2015 /$ \\
& \multicolumn{1}{c}{06} & \multicolumn{1}{c}{07} & \multicolumn{1}{c}{08} & \multicolumn{1}{c}{09} & \multicolumn{1}{c}{10} & \multicolumn{1}{c}{11} & \multicolumn{1}{c}{12} & \multicolumn{1}{c}{13} & \multicolumn{1}{c}{14} & \multicolumn{1}{c}{15} & \multicolumn{1}{c}{16} \\
\hline Bács-Kiskun & 20,8 & 20,0 & 17,6 & 19,1 & 18,4 & 17,9 & 18,8 & 12,9 & 12,5 & 13,9 & 11,9 \\
Baranya & 57,1 & 61,0 & 65,4 & 66,0 & 67,1 & 65,5 & 64,9 & 62,1 & 57,9 & 58,5 & 56,2 \\
Békés & 21,5 & 22,8 & 20,0 & 24,4 & 23,3 & 21,2 & 18,2 & 11,8 & 10,9 & 9,9 & 12,5 \\
Borsod-Abaúj-Zemplén & 30,6 & 32,7 & 37,4 & 39,6 & 40,1 & 39,8 & 40,3 & 39,2 & 38,6 & 38,1 & 37,5 \\
Budapest & 66,2 & 68,1 & 76,8 & 78,3 & 79,0 & 80,0 & 79,6 & 83,7 & 84,1 & 85,5 & 86,1 \\
Csongrád & 61,1 & 61,6 & 65,8 & 66,7 & 69,2 & 68,4 & 67,7 & 67,4 & 66,1 & 65,7 & 63,6 \\
Fejér & 18,5 & 17,6 & 23,2 & 23,9 & 19,6 & 19,3 & 17,3 & 13,6 & 13,6 & 10,7 & 9,4 \\
Győr-Moson-Sopron & 50,7 & 52,1 & 51,6 & 51,1 & 50,5 & 52,6 & 51,4 & 51,5 & 49,5 & 52,0 & 48,2 \\
Hajdú-Bihar & 46,2 & 51,2 & 57,6 & 60,3 & 62,7 & 65,2 & 64,7 & 62,9 & 63,0 & 64,8 & 61,2 \\
Heves & 32,5 & 31,0 & 30,8 & 32,4 & 34,0 & 32,7 & 35,8 & 29,9 & 25,7 & 26,8 & 25,2 \\
Jász-Nagykun-Szolnok & 15,4 & 15,0 & 16,3 & 19,4 & 15,0 & 12,1 & 13,9 & 9,4 & 7,2 & 9,4 & 8,8 \\
Komárom-Esztergom & 10,8 & 9,2 & 8,5 & 9,1 & 8,5 & 9,1 & 9,8 & 7,5 & 4,8 & 4,9 & 4,9 \\
Nógrád & 4,2 & 3,5 & 3,0 & 3,6 & 6,0 & 5,9 & 4,9 & 0,0 & 0,0 & 0,0 & 0,0 \\
Pest & 9,9 & 9,8 & 8,4 & 9,7 & 9,5 & 8,9 & 9,1 & 8,0 & 7,4 & 7,0 & 5,7 \\
Somogy & 22,0 & 19,5 & 16,6 & 19,2 & 18,2 & 20,2 & 19,6 & 16,5 & 17,4 & 18,0 & 13,9 \\
Szabolcs-Szatmár-B. & 40,2 & 39,1 & 36,0 & 33,1 & 32,8 & 30,9 & 31,6 & 25,7 & 22,7 & 23,1 & 19,7 \\
Tolna & 14,0 & 12,5 & 10,2 & 10,8 & 10,5 & 8,2 & 8,7 & 7,8 & 5,3 & 6,8 & 4,8 \\
Vas & 23,9 & 23,7 & 27,1 & 30,9 & 28,0 & 28,0 & 26,5 & 22,2 & 16,0 & 17,6 & 19,0 \\
Veszprém & 26,0 & 23,7 & 27,5 & 28,5 & 28,6 & 27,1 & 24,8 & 24,2 & 21,1 & 23,6 & 22,3 \\
Zala & 8,5 & 8,7 & 15,4 & 16,7 & 18,1 & 15,2 & 17,0 & 16,9 & 20,2 & 17,7 & 15,6 \\
\hline
\end{tabular}

Adatok forrása: az Oktatási Hivatal felvételi adatbázisai. 
2. ábra: Adott megyébe (képzés telephelye) felvettek és az adott megyéből

(lakóhely/középiskola alapján) felvételt nyertek aránya

Ratio of admitted students by permanent residence/secondary school by county and admissions by county

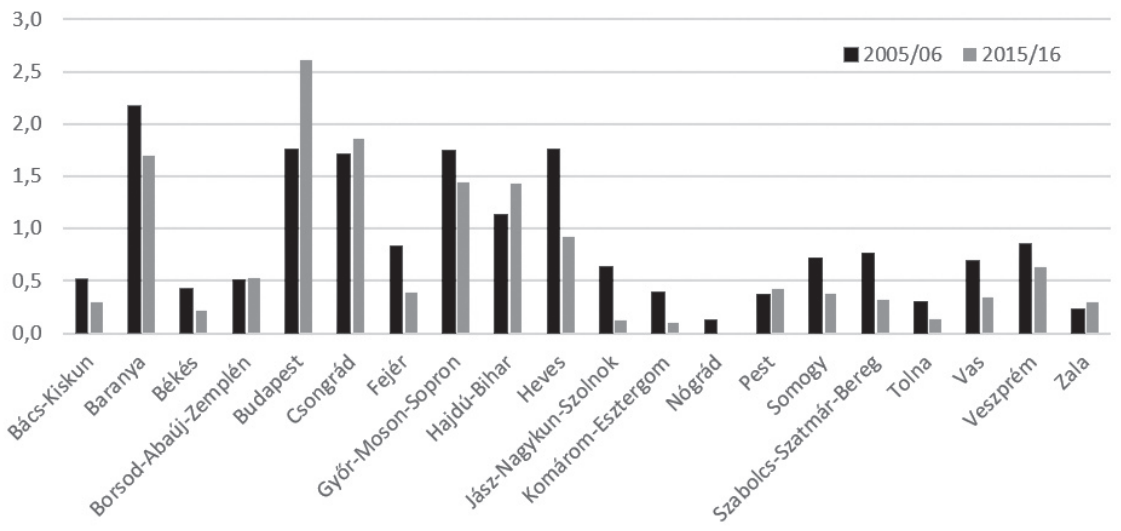

Adatok forrása: az Oktatási Hivatal felvételi adatbázisai.

A vizsgált tíz évben jelentősen átalakult a megyék helyzete. A 2005/06-os évben még öt megyében láthatunk magas szintű vonzást: Baranya $(2,17)$, Budapest $(1,76)$, Heves $(1,76)$, Győr-Moson-Sopron $(1,74)$ és Csongrád $(1,71)$. Baranya megye teljesítménye rendkívül pozitív, főleg, hogy Budapestet is megelőzi, ez egyértelműen a rövid ciklusú képzések felfuttató hatásának tudható be (a megye megtartó ereje a nagy vidéki szellemi központokhoz hasonló, a regionális felvételi bázis alacsony, ugyanakkor nagyon erős országos vonzerővel bír). Legalacsonyabb mértékủ vonzerővel Nógrád $(0,12)$, Zala $(0,23)$ és Tolna $(0,30)$ megyék rendelkeznek.

Napjainkra már csak három esetben (Budapest 2,61; Csongrád 1,87; Baranya 1,70$)$ volt kimutatható jelentős vonzerő. Budapest primátusa megkérdőjelezhetetlen, egyértelmű, időben felfutó fejlődés azonosítható. Baranya visszaesett, míg Csongrád tudott javítani a pozícióján. Nógrád megyében megszűnt a képzés, míg a legnagyobb mértékű csökkenést arányait tekintve Jász-NagykunSzolnok (0,63-ról 0,13-ra) és Komárom-Esztergom (0,39-ről 0,10-re) esetében láthatjuk. Viszonylag jó pozícióból induló erőteljesebb javulást egyedül HajdúBihar (1,13-ról 1,43-ra) megyénél találunk.

Abszolút számokat vizsgálva - méreténél fogva, fövárosi rangjából és munkaerőpiaci adottságaiból adódóan is - Budapest vonzereje a legnagyobb. A legalacsonyabb értékekkel Nógrád, Zala és Tolna megye rendelkezik.

Mindezek alapján megállapítható, hogy a hazai beiskolázási vonzáskörzetek átalakultak, a csökkenő hallgatói létszámok mellett Budapest tudott jelentős vonzerö- és megtartóerö-növekedést elérni, valamint, hogy a legerősebb fövárosi és vidéki szellemi központok szívták el a hallgatókat a kisebb felsőoktatási intézményellátottságú területekről. 


\section{A továbblépési lehetőség - munkaerőpiaci információk}

A felsőoktatási intézmények célja, hogy megtartsák korábbi pozícióikat. Nagyobb figyelmet kell fordítaniuk a hallgatói elvárásokra, valamint a piaci igényekre. A felsőoktatási intézményekben ennek érdekében szükség van marketinginformációs rendszer kiépítésére (Hetesi 2010; Kuráth, Törőcsik 2011), így többek között a felvételi és hallgatói statisztikák részletesebb kidolgozására és elemzésére (beleértve a versenytárs-elemzéseket is), valamint az érintett szereplők rendszeres és részletes megkérdezésére. A felsőfokú intézmények érdeke, hogy pontos ismeretekkel rendelkezzenek a végzett hallgatók további sorsáról, amelyből képet alkothatnak arról, hogy a kibocsátott diákok összetétele és tudása illeszkedik-e a munkaerőpiaci kereslethez. A nem megfelelés megkérdőjelezheti a felsőfokú intézmény működésének létjogosultságát.

A hazai felsőoktatási törvény kötelezővé tette a pályakövetés vizsgálatát. A diplomás pályakövető rendszer (DPR) keretében végzett felmérések az elmúlt 8 évben országosan is összehasonlítható eredményeket adtak. Az intézményi DPR mellett az adatkezelési törvény, valamint a különböző állami adminisztratív adatbázisok összehangolásának köszönhetően kialakult a pályakövetés egy másik módja, az állami adminisztratív adatbázisok integrációjával. A DPR nemcsak a felsőfokú intézmények stratégiájának kialakításához, módosításához szükséges, hanem feladata a felsőoktatásba készülők, pályaválasztók informálása is, a központi tájékoztató és regisztrációs felületeken igen hatékonyan járulhatnak hozzá a továbbtanulási döntéshez. A pályakövetési vizsgálatok eredményei iránt növekszik társadalmi igény, ami a nemzeti adatgyüjtő rendszerek kiépítése felé mutat. A nemzetközi trend a potenciális hallgatók iránti növekvő figyelem (Veroszta 2018).

Az Európai Unióban kiemelt prioritás a tudásalapú gazdasághoz való hozzájárulás. 2017-ben az Európai Tanács kinyilvánította, hogy szükség van a pályakövetési vizsgálatok azonos szintjének kialakítására - nyitott koordinációs mechanizmuson keresztül. A javaslat az Eurograduate felmérés eredményeit vette alapul (Európai Bizottság 2017; Mühleck 2016).

\section{Összefoglalás}

A hazai intézmények vonzáskörzete átalakult, a hazai merítési bázis csökkenésével a hallgatói jelentkezések kezdeti csökkenése ugyan megállt, de a felsőoktatási intézmények közötti verseny növekszik a potenciális hallgatókért. A felvételizők és a hallgatók létszámmegoszlását vizsgálva olyan társadalmi egyenlőtlenségek mutatkoznak, amelyek egyaránt összefüggésbe hozhatók az adott térségek gazdasági fejlettségével és a felsőoktatás területi szerkezetével. Budapest pozíciója a vizsgált tíz évben erősödött. Ez erőteljes kihívást jelent a 
vidéki intézmények számára. Új stratégiát kell a felsőfokú intézményeknek kidolgozniuk a fennmaradásukra, az elért pozícióik megtartására.

A hazai felsőoktatási törvény a pályakövetés lefolytatását írja elő kötelezően a diplomás pályakövető rendszer kidolgozásával. A felsőfokú intézmények felelössége és joga eldönteni, milyen mértékben használják fel rövidebbhosszabb távú céljaik eléréséhez ezeket az információkat. A pályakövetés nemcsak a felsőfokú intézmények számára fontos és egyre inkább nélkülözhetetlen eszköz, de alapvetően hasznos a pályaválasztók tájékoztatásában is. Az oktatáspolitikusok és a felsőfokú intézmények vezetői a diplomás pályakövető rendszer segítségével megértik, átlátják a felvételizők döntési prioritásait, és ez is hozzájárul a munkaerőpiac és a felsőoktatás összehangolásához.

\section{Irodalom}

Balogh G. (2015): A regionális tehetséggazdálkodás vizsgálati módszerei a Pécsi Tudományegyetem Közgazdaságtudomány Kar hallgatóinak példáján. Tér és Társadalom, 2., 127-148. http://doi.org/c2cw

Berács J., Derényi A., Kádár-Csoboth P., Kováts G., Polónyi I., Temesi J. (2017): Magyar Felsőoktatás 2016. Stratégiai helyzetértékelés. Budapesti Corvinus Egyetem, Budapest

Berács J., Derényi A., Kováts G., Polónyi I., Temesi J. (2015): Magyar felsőoktatás 2014. Stratégiai helyzetértékelés. Budapesti Corvinus Egyetem, Budapest

Duga, Zs., Szontágh, K. (2012): Student mobility, a panorama of the situation in Hungary. In: Bélyácz, I., Fogarasi, J., Szabó, K., Szász, E. (eds.): Knowledge and sustainable economic development. Partium Publisher, Oradea

Európai Bizottság (2017): A Tanács ajánlása a pályakövetésról. COM(2017)249 final. http://eur-lex.europa. eu/legal-content/HU/TXT/PDF/?uri=CELEX:52017DC0249\&from=HU (Letöltés: 2018. március 8.)

Filep B., Tamándl L. (2011): Az intézményi marketing és a DPR kapcsolata a Széchenyi István Egyetemen. Felsőoktatási Mühely, 2., 93-104.

Fokozatváltás a felsőoktatásban. http://www.kormany.hu/download/d/90/30000/fels\%C5\%91 oktat\%C3\%A1si\%20koncepci\%C3\%B3.pdf (Letöltés: 2018. március 16.)

Halász G. (2012): Finanszírozási reformok a felsőoktatásban: nemzetközi összehasonlító elemzés. In: Temesi J. (szerk.): Felsőoktatás-finanszírozás. Nemzetközi tendenciák és hazai helyzet. AULA Kiadó Kft., Budapest, 11-66.

Hetesi E. (2010): A marketing információs rendszer és a felsőoktatási elégedettségi kutatások módszertani problémái. In: Törőcsik M., Kuráth G. (szerk.): Egyetemi marketing: marketing a felsőoktatásban. Pécsi Tudományegyetem, Pécs, 103-123.

Hrubos I. (2014): Expanzió, határok nélkül. Educatio, 2., 205-215.

Hrubos I. (szerk.) (2012): Elefántcsonttoronyból világitótorony. A felsőoktatási intézmények misszióinak bőviulése, átalakulása. AULA Kiadó Kft., Budapest

Keresztes, É. R. (2014): Financing tertiary education: international and Hungarian examples of tuition fees. European Scientific Journal, 28., 205-218.

Komlódiné Pozsgai Gy. (2014): A külföldi hallgatók egyetemválasztási szempontjainak a szerepe a PTE nemzetközi vonzerőfejlesztésében. Marketing és Menedzsment, 2., 3-19.

Kováts G., Temesi J. (szerk.) (2018): A magyar felsőoktatás egy évtizede 2008-2017. Budapesti Corvinus Egyetem, Budapest

Kuráth G. (2007): A hazai felsőoktatási intézmények regionális hatásának vizsgálata a beiskolázási marketingmunkában. Tér és Társadalom, 4., 95-110. http://doi.org/c2cx 
Kuráth G., Törőcsik M. (2011): Felsőoktatási marketingkihívások. Felsőoktatási Műhely, 2., 15-23.

Kuráth G., Héra-Tóth A., Sipos N. (2017): PTE Felvételi kutatás 2017. Pécsi Tudományegyetem, Pécs

Müchleck, K. (ed.) (2016): Testing the feasibility of a European graduate study. Final report of the eurograduate feasibility study. German Center for Higher Education Research and Science Studies, Hannover

Olsovszkyné Némedi A. (2014): Hallgatói és munkaerő-piaci elégedettségi vizsgálatok a felsőoktatási marketingben. PhD értékezés. Kaposvári Egyetem, Kaposvár

Polónyi I. (2012): A hazai felsőoktatás állami finanszírozásának története, 1990-2011. In: Temesi J. (szerk.): Felsőoktatás-finanszírozás. Nemzetközi tendenciák és hazai helyzet. AULA Kiadó Kft., Budapest, 199-254.

Polónyi I. (2014): Régi, új felsőoktatási expanzió. Educatio, 2., 185-204.

Polónyi I. (2016): Felsőoktatás a koncepciók keresztútján. Köz-gazdaság, 2., 209-222.

Polónyi I. (2018): A hazai felsőoktatás elmúlt 10 évének néhány gazdasági jellemzője. In: Kováts G., Temesi J. (szerk.): A magyar felsőoktatás egy évtizede 2008-2017. Budapesti Corvinus Egyetem, Budapest, 79-101.

Rámháp Sz. (2017): Felsőoktatási továbbtanulási motivációk Magyarországon a változó ifjúság és a piacosodó felsőoktatás tükrében. PhD értekezés. Széchenyi István Egyetem, Győr

Rechnitzer J. (2010): A felsőoktatás regionalitása, a régiók és a felsőoktatás. In: Törőcsik M., Kuráth G. (szerk.): Egyetemi marketing, marketing a felsőoktatásban. Pécsi Tudományegyetem, Pécs, 35-48.

Rechnitzer J. (2011): A felsőoktatás tere, a tér felsőoktatása. In: Berács J., Hrubos I., Temesi J. (szerk.): Magyar Felsőoktatás 2010. Konferenciadokumentumok. Budapesti Corvinus Egyetem, Budapest, $70-86$.

Törőcsik M. (szerk.) (2015): A Z generáció magatartása és kommunikációja. Pécsi Tudományegyetem, Pécs

Veroszta Zs. (2018): A magyarországi diplomás pályakövetési rendszer kiépülése és eredményei. A hazai felsőoktatás elmúlt 10 évének néhány gazdasági jellemzője. In: Kováts G., Temesi J. (szerk.): A magyar felsőoktatás egy évtizede 2008-2017. Budapesti Corvinus Egyetem, Budapest, 202-212. 